ÁGNes GYÖRKE

Károli Gáspár Református Egyetem

\title{
Contemporary Hungarian Women's Writing and Cosmopolitanism
}

\section{Feminism and Women's Writing in Hungary}

Although more and more female writers have appeared on the Hungarian literary scene, scholarly writing about contemporary Hungarian women's fiction is rather scarce, especially in English. Compared to the enthusiastic critical response to Anglophone women's writings, the novels of Zadie Smith, Monica Ali, and Bernardine Evaristo, ${ }^{1}$ for instance, the difference is rather stunning, and it cannot be explained by the relatively small size of the Hungarian literary establishment alone. After the publication of Night Time Zoo (2005), an outspoken anthology that explores female sexuality, ${ }^{2}$ a number of writers complained that their work is not taken seriously in Hungary, ${ }^{3}$ and feminist critics repeatedly called attention to the structural inequalities that characterise the institutions

1 Salman Rushdie called Zadie Smith's White Teeth an "astonishingly assured debut" (Jackson), while Bernardine Evaristo was the first black woman who won the Booker Prize in 2019. Both White Teeth and Monica Ali's Brick Lane were hailed as exemplary novels that illustrate "why postcolonial frameworks continue to be relevant when discussing 'black British literature”" (Upstone 333).

2 Out of the 33 pieces the volume includes, 30 are written by contemporary writers.

3 For a detailed analysis of feminist criticism in Hungary see, for instance, Séllei (2007), Várnagyi (2011), Horváth (2014) (in Hungarian). 
of the Hungarian academic world and publishing industry. ${ }^{4}$ This is partly due to the fact that feminist literary and cultural criticism appeared in the country after the regime change in 1989 (Séllei 148), which was already the threshold of third wave feminism in Western Europe and the United States. Hungarian feminism has been called "belated" for this reason (Várnagyi 24-25, 29; Séllei 140), along with many other approaches such as cultural studies and postcolonial theory. ${ }^{5}$

It is not only the institutional inequalities that hinder the emergence of a strong tradition of women's writing in East-Central Europe, however, but the interiorized stigma of the very category:

many women writers resisted being labelled as 'female writers' because of the generally derogatory connotations in most of these cultures: the stereotypical view of Czech women's writing as 'low-brow' or Polish critics' dismissal of its 'sentimental and mawkish', are typical of the whole region (Hawkesworth 200).

In Hungary, too, some critics do not acknowledge women's writing as a distinct literary category: in his review of Noémi Kiss's Trans, for instance, a volume I explore later in this article, Péter Rácz claimed that, though the book is an interesting and genuine contribution to contemporary literature, it is burdened by the constant repetition of the assertion: "I am a woman"; "I am a woman writer" (Rácz 2007).

In other words, the lack of enthusiasm concerning women's writing in Hungary cannot be understood without being aware of the stigmatization of feminism in the region. This is partly due to the fact that feminist literary criticism does not solely evaluate the significance of literary works on the basis of aesthetic categories, similarly to postcolonial criticism, cultural studies, and many other

4 Andrea Petö, however, argues that all main book distribution network companies were headed by women in the 1990s: "Of some 25 publishing companies concerned with literature, five are owned by women (Liget, Széphalom, Seneca, Nap, Kortárs)” (Pető 250).

5 The belatedness model, however, cannot adequately map the situation of women's writing in the region, as it is unable to explain the specific genealogy of feminism in Central and Eastern Europe. As Pető points out, "[a]fter 1989, with the democratization of the country, space for women writers opened up. But then, as the subsidised publishing system collapsed, women writers lost their advantage of positive discrimination. The decline of subsidized publishing also meant that edition sizes-usually between 30,000 and 100,000 before 1989 - shrank to the 2,00o copies which is the norm today" (Pető 250). 
approaches foreground the role cultural and social contexts plays in interpretation. ${ }^{6}$ The insistence on a supposedly pure aesthetic judgement is no doubt a response to the crudely ideological readings produced under state socialism in this region: after the Second World War, advocating the Stalinist dogma offered new opportunities for writers regardless of artistic quality. On the other hand, feminist criticism is often regarded as an instance of "positive discrimination," an assumption which, apart from being a crude simplification, is also burdened by the communist legacy: references to the ways in which positive discrimination was used under communism is often enough to dismiss the need to redefine this principle after the regime change. Due to this stigmatization, Hungarian women writers often do not identify as feminist publicly or refuse to put their work into the (derogatory) category of "women's writing." Though Zsuzsa Bruria Forgács, the main editor of the Night Time Zoo anthologies was very clear about the purpose of the series, ${ }^{7}$ which was to represent women's perspectives in Hungarian literature (Lennert; Szilva 2), Agáta Gordon, her co-editor contended that " $[\mathrm{w}] \mathrm{e}$ do not mention that we are feminist not because we are ashamed of being feminists, but because we do not want to have a stigma which hinders us in achieving our aim... We are of course feminists, but we do not use this word in Hungary" (Szilva 25). ${ }^{8}$ Noémi Szécsi, whose work I discuss later in this essay, even protested against the category of women's writing in a 2010 interview:

I don't know why establishing the notion of "women's literature" is good for feminism. It is a disadvantage for me, as I feel excluded from "the great tradition." It is important for women writers to gain more spacethis is needed by the overwhelmingly female readerships as well-but it would be silly to divide readers into two groups. (Farkas 2010, qtd. in Várnagyi 28-29)

6 For an excellent summary in Hungarian see Györgyi Horváth’s Utazó elméletek (Travelling Theories) (2014).

7 The anthology was followed by three other volumes that transformed this publication into a major feminist series called Uncovered Psyché. All latter volumes of the series address topics relevant for female writers and readers such as the female body (Thirsty Oasis: Anthology on the Female Body, mother-daughter relationship (Jungle in the Heart: Daughters' and Mothers' Anthology), and father-daughter relationship (The Dog of the Heart: Daughters' and Fathers' Anthology).

8 As Katalin Fábián points out, women's groups in Hungary often refuse to label themselves in political terms, mainly due to the confines conventional definitions of politics relies on (17-18). Nóra Séllei has also explored the resistance against feminism in the country, which she compared to the fear of wolves (Séllei 11, in Hungarian). 
Nevertheless, Szécsi still located her work in a transnational female literary tradition two years later:

I used to read mainly Hungarian literature up until the age of 18 , but as soon as I could read in English and in Finnish I was mesmerised by British and Scandinavian women writers. So as a "conscious reader" I looked for different attitudes from our very political, masculine, "heavy" literary tradition. (Orzóy)

Perhaps this changing attitude suggests that despite the apparent risk of exclusion, women writers are becoming more vocal about their position and voice? ${ }^{9}$

Though it would be overly ambitious to offer an in-depth analysis of the current literary scene in Hungary in this short essay, my paper aims to map some of the key themes contemporary women's writers engage with. I would claim, not unlike Márta Várnagyi, that although not all women's writings are feminist by definition, the analysis of these texts nevertheless foregrounds issues significant for feminist criticism in its different local contexts. The literary works I touch upon in the next section are Noémi Szécsi's The Finno-Ugrian Vampire, Noémi Kiss's Trans and Virág Erdős's Luminous Bodies: 100 Little Budapest, ${ }^{10}$ which I read as examples of cosmopolitan feminist engagement with city life.

\section{Cosmopolitan Feminist Visions: Noémi Szécsi, Noémi Kiss and Virág Erdős}

Cosmopolitan feminism is characterised by the twofold desire to cross conventional borders and limits yet locate the phenomena explored in a "grounded" urban environment. Some of these issues are not entirely new, of course; the idea of women going beyond their designated space is perhaps one of the most significant themes women writers have dealt with ever since the first wave of feminism, aiming to counteract "the fundamental kinetopia" that characterizes traditional constructions of femininity (Shands 3 ). The focus on the particular and the embodied also has a long tradition in feminist discourse: as Adrienne Rich has

9 Another very self-conscious feminist intervention in the past few years has been the launching of the online blog called Literary Centrifuge (Irodalmi centrifuga), founded in 2008, which aims to advocate women's perspectives and values https:// centrifuga.blog.hu/

10 Other examples would include Andrea Tompa, Edina Szvoren, Krisztina Tóth, among other female writers. 
famously put it, mapping our place in the world begins "not with a continent or a country or a house, but with the geography closest in - the body" (Rich 212). A cosmopolitan feminist approach, then, cannot be anything but subversive and grounded. As opposed to the Kantian concept of cosmopolitanism, which has been critiqued for failing to take the experiences of particular social groups and geographical regions into account (Vieten 3; Fitzgerald 80), cosmopolitan feminism focuses on the local and the embodied, offering insights into "the ways in which ideas of the domestic, familial and intimate can configure [cosmopolitan] spaces" (Fitzgerald 81). As I hope to show in this essay, the texts I discuss explore various crossings both on the level of form and content, while they engage with the mundane, affective aspects of everyday life in an emphatically urban environment. Apart from foregrounding women's experience, these narratives challenge "heavy" national literary traditions and point towards a distinct feminist aesthetics in contemporary Hungarian literature. ${ }^{11}$

Published in 2002, ${ }^{12}$ The Finno-Ugrian Vampire problematizes received national traditions, offering a view of East-Central Europe as an unbarred, culturally hybrid space. ${ }^{13}$ As Tibor Fischer argues, since vampirism is associated with Hungary and Transylvania in the Anglo-Saxon world, Szécsi's novel is "a clever satire on the whole notion of Hungarian-ness, nationalism and the stereotypes of Eastern Europe" (Fischer 2012). The Finno-Ugrian Vampire is, however, by no means a conventional vampire story: instead of bloodletting and

11 Szécsi refuses both Hungarian and cosmopolitan identities, claiming that "I don’t like getting involved in causes, communities and movements, I don't like building Hungarian and cosmopolitan identities for myself, because I insist on moving freely between categories, on keeping every door and window open. This is my "notion of freedom as a writer" (Orzóy 2012). The idea of cosmopolitan feminism, however, is based on the refusal to identify both with heavy-handed national traditions and Westocentric cosmopolitanism: the position this approach delineates is akin to her notion of artistic freedom.

12 The novel was published in English in 2012 by Stork Press, a small publishing house founded in 2011 and active till 2016.

13 According to Dávid Szolláth, contemporary Hungarian novels that depict the historical past of Central Europe tend to portray the country as a borderland of cultural hybridity (461). His analysis is based on the works of four male authors, Ádám Bodor, László Darvasi, Zsolt Láng and Miklós Mészöly, which demonstrate that the specific Central European experience is often narrated in a magic realistic framework, just like Latin American stories. Central Europe appears as a peripheral transit zone in these writings, which is "characterized by cultural hybridity and ethnical and religious heterogeneity" (Szolláth 462) and is expressed through the portrayal of places such as Transdanubia (Pannonia) and the historical Transylvania. 
scary scenes, the Bildung of the narrator is in the centre of attention, as Szécsi herself points out (Orzóy 2012). The novel depicts two very different vampires: grandma, the mighty Finno-Ugrian predator allegorizes a cultural heritage based on stereotypes, while Jerne, the narrator of the novel, resists this very tradition. The difference between the two vampires is clear from the very beginning of the novel: while grandma is a femme fatale, for instance, it never turns out whether Jerne is male or female in the original text (though in the English translation she is clearly gendered as a woman). ${ }^{14}$ The narrative destabilizes readers in their beliefs concerning established traditions and gender norms: The Finno-Ugrian Vampire depicts East-Central Europe as a heterogeneous and cosmopolitan space, while it also offers a critique of national stereotypes.

The very first sentence of the novel reveals an interest in cosmopolitanism: "I could call my grandmother cosmopolitan, since she has visited virtually every corner of the globe and everywhere felt immediately at home" (Szécsi 1). Furthermore, grandma is not simply a Hungarian vampire, but a worldly Finno-Ugrian predator, as she is not satisfied with the parochial national label (Finno-Ugrian refers to the group of languages in the Uralic language family including Hungarian, Finnish and Estonian, among others). Her resistance to being called a Hungarian vampire is very telling: "What a vulgar notion! Just think how some arrogant Anglo-Saxon vampire would react if I presented myself as a Hungarian vampire... But Finno-Ugrian: that arouses instant respect and lends me an aura of the exotic" (Szécsi 23). However, it quickly turns out that grandma is a nationalist at heart: unlike her, "not every citizen of the world is likely to use a china tooth mug decorated with a map of Great Hungary and the irredentist slogan 'Transylvania is Ours!'” (Szécsi 1). The map on her mug depicts Hungary at the time of the Austro-Hungarian Monarchy, suggesting that she is nostalgic of national greatness and her cosmopolitan identity is only for show. Jerne's intellectual and subversive cosmopolitanism, however, critiques this very tradition: due to the education she receives in England, she learns to swear in French, and often repeats the names of prominent intellectuals to express her disdain: “'what a load of Lacan'; 'a positive pack of Derrida' [and]

14 Szécsi employed this trick since she considered it "fun": "I remember reading a short story by Rosa Liksom, a Finnish writer where the gender of the narrator wasn't clear until the very end, and I remember thinking, 'well, it's fun.' It's much more difficult to create a novel based on this idea, but with the help of our language you can at least play with it" (Orzóy 2012). In the translation, this ambiguity is inevitable lost, she is female: she was already a woman in the 2005 Polish translation, Peter Sherwood only followed this in the English text (Orzóy 2012). 
'Foucault!"' (Szécsi 14). Her "repertoire” is based on a very Western intellectual tradition, whereas grandma often dreams of the classical Hungarian writer, Mór Jókai (Szécsi 21), which, taken out of context, is immediately subverted in her ironical tale. While grandma's nationalist cosmopolitanism is grandiose yet empty, then, Jerne's "vampirism" and the very narrative she tells offer a more subversive and "grounded" cosmopolitan tale, which I read as example of cosmopolitan feminism.

The Finno-Ugrian Vampire showcases the myriad details of everyday life in contemporary Budapest. Instead of a Gothic castle, which is the proper location of vampires, Jerne and her grandma live in a mundane two-roomed flat in the city:

So, giving the lie to those vaunted vampire legends, we don't live in some ruined castle.... The house where we have a top floor flat has every modern convenience and is in excellent condition, thanks to the house representative's contacts and string-pulling. (Szécsi 6)

Far from evoking a Gothic world populated by stereotypical characters, Jerne's narrative engages with the mundane aspects of everyday life. Urban places are depicted in the novel at different scales, ranging from domestic interiors (the bathroom, a small attic room, the stairwell, etc.) to mainstream sights of Budapest such as City Park, where grandma lives, and Old Buda Castle, where a nightclub reminds her of "unforgettable blood sucking memories" (Szécsi 6). Jerne's tale offers a glimpse into contemporary public issues such as the dominance of the informal "old boys' networks" in the country, among many others. Her hesitant "vampirism" literally triumphs over grandiosity at the end of the novel: grandma is murdered in a small hotel room in Tallin, Estonia, by Jerne's gay friend, Uncle Oscar. This triumph might also be read as the victory of a more timid yet subversive cosmopolitanism over grandiose national stereotypes.

Noémi Kiss's collection of short stories, Trans, published in 2006, also explores the mundane aspects of everyday life, yet most of the stories in the volume are set outside the borders of Hungary. Trans thematises all kinds of border crossings including geographical, emotional and sexual: it shows the psychological drama of everyday interactions, offering sensitive visions of female subjectivity. The most memorable story in the collection is perhaps the first one entitled "Trans: Passage to a Detour," which has been published in English by Hungarian Literature Online. ${ }^{15}$ The short story is set in Berlin, where the narra-

15 See https://tinyurl.com/y5rrwaw3. 
tor, in transit, ends up witnessing a murder committed in a gay bar. "Trans" is the story of initiation and loneliness, while the city, as if it were another character we get to know for a short while, witnesses the suffering of the flesh and blood characters; this is a central theme in Kiss's novel, Ikeranya (Mother of Twins), as well. The focus on the embodied visions and experiences of women, as well as the obstacles and barriers to these visions, reveals a cosmopolitan feminist interest. As the narrator walks to the bar along the inert roads in "Trans," she registers the desolate cityscapes as a flaneuse $^{16}$ par excellence:

The sidewalk along which we proceeded was a long strip into infinity. There was no point looking to the right or life, all you could see were tubes and barrels, iron girders and two high walls. No, this road doesn't lead to infinity, for our glance always bumps into one wall or another. I had never seen a street so emblematic of solitude as that one. (Kiss 2008)

This is a vision of radical openness framed and constrained, not unlike the very text itself (the narrator struggles to register the events she witnesses), which is a theme that recurs in many other stories as well, following close behind the transgressions characters perform in the volume.

The city has also inspired contemporary Hungarian poetry and the arts, as Erdős Virág's recent volume Illuminated Bodies: 10o Little Budapest (2016) shows. ${ }^{17}$ Erdős is a truly versatile artist who illuminated her own volume with minimalistic photographs of Budapest and set some of her poems to music. ${ }^{18}$ As the very title suggests, the volume offers apparently insignificant ("little") and embodied visions of the metropolis in a truly cosmopolitan feminist fashion, which is both a thematic and a formal feature of this collection. The photographs in this volume do not simply illustrate the poems: the association between text and image is often latent, the only thing that seems to be certain is that both comment on various aspects of city life. The collection, on the one hand, reveals the impossibility to "capture" the capital except in such incomplete and

16 For gendered readings of flanerie see Debora Parson's Streetwalking the Metropolis (2000) and Elizabeth Wilson's The Sphinx in the City (1992) and Contradictions of Culture (2001), among many others.

17 Other well-known female poets include Anna Szabó T, Krisztina Tóth and Orsolya Karafiáth, among others.

18 For instance, "Szuvenír" (Souvenir) https://tinyurl.com/y3kspsal; "Az én vétkem" (Mea culpa) https://tinyurl.com/y6swor8j. 
often contradictory snapshots, while, on the other, it nonetheless undermines conventional ways of reading and expands the concept of literary and artistic genres. The speaker of the poems is a flâneuse who registers sense impression from an emphatically peripheral angle, similar to the photographer, yet her gaze never controls the spectacles described. Images of red, white and green plastic cans illuminate a poem titled "the purity of our revolution," for instance, which portrays a tram stop near Corvin Alley, an important location of the 1956 Revolution, and ends with the image of a woman greeting passengers and asking for money. Found objects abound in the volume (a shoe on top of a pillar, torn advertisements, ashtrays full of stubs, etc.) as well as bricks, leaves, plants framed and constrained by bricks. These glimpses into everyday life framed by the city, not unlike the camera frames the photographs, reveal colourful, creative, and socially responsible views of the capital.

\section{Conclusion}

As I have argued in this essay, Szécsi's, Kiss's and Erdős's writings do not only explore the idea that women need to go beyond their designated space, but also engage with the mundane, affective aspects of everyday life. This interest in the embodied, hesitant and peripheral facets of city life is a feature of cosmopolitan feminism, which is characterised by the twofold desire to cross conventional limits, yet locate this experience in a "grounded" urban environment. Furthermore, as Jerne's narrative reveals, cosmopolitan feminism might offer an alternative to masculine and "heavy" national literary traditions in the East-Central European region. Far from only exposing all-too-intimate insights into women's experience, then, these texts point towards a distinct feminist aesthetics.

\section{| References}

Erdős, Virág. Világító testek: 100 kis Budapest. Budapest: Magvető, 2016.

Fábián, Katalin. Contemporary Women's Movements in Hungary: Globalization, Democracy, and Gender Equality. Baltimore: The John Hopkins UP, 2009.

Farkas Anita. "Irodalmi nemek." Demokrata 17 February 2010, https://tinyurl. com/y5zexons. Accessed 18 August 2019.

Fischer, Tibor. “The Finno-Ugrian Vampire by Noémi Szécsi." The Guardian 12 October 2012, https://tinyurl.com/y74xrhw9. Accessed 18 August 2019. 
Fischer, Tibor. Under the Frog. London: Penguin, 1993.

Fitzgerald, Ruth P. and Maila Stevens. "Editorial for Special Section 'Gendering Cosmopolitanisms: Recognition, Belonging and Difference, Women's Studies International Forum." Women's Studies International Forum 67 (2018): 80-84.

Forgács, Zsuzsa Bruria, Agáta Gordon and Bódis Kriszta. Night Time Zoo: Anthology about Female Sexuality. Budapest: Jonathan Miller, 2005.

Hawkesworth, Celia, ed. A History of Central European Women's Writing. London: Palgrave Macmillan, 2001.

Horváth, Györgyi. Utazó elméletek: Angolszász politizáló elméletei kelet-európai kontextusban. Budapest: Balassi Kiadó, 2014.

Jackson, Kevin. “The Next Generational Zadie Smith.” The New Yorker, 18 October 1999, https://tinyurl.com/ybpzzdpz. Accessed 30 January 2020.

Kiss, Noémi. Ikeranya. Budapest: Magvető, 2013.

Kiss, Noémi. Trans. Budapest: Magvető, 2006.

Kiss, Noémi. "Passage to a Detour." Hungarian Literature Online, https://tinyurl. com/y5rrwaw3. Accessed 6 September 2019.

Lennert, Tímea. “A Kitakart Psyché utóéletei." Irodalmi Jelen, 11 May 2012, https://tinyurl.com/yakg47ng. Accessed 18 August 2019.

Nádas, Péter. "A kettős látás dícsérete: Zsuzsa Bánk írt egy velejéig magyar regényt németül." Élet és Irodalom 15 Nov, 2002. Online.

Orzóy, Ágnes. “I Like Being an Outsider’: Interview with Noémi Szécsi.” Hungarian Literature Online, 10 Dec. 2012, https://tinyurl.com/y2eobfcq. Accessed 18 August 2019.

Parsons, Deborah. Streetwalking the Metropolis: Women, City and Modernity. Oxford: Oxford University Press, 2000.

Pető, Andrea. "Hungarian Women's Writing 1945-95." A History of Central European Women's Writing. Ed. Celia Hawksworth. London: Palgrave Macmillan, 2001. 240-255.

Rácz, Péter. “Ex Libris.” Élet és Irodalom 51.6 (2007), https://tinyurl.com/ y6kktm25. Accessed 6 September 2019.

Rich, Adrienne. "Notes towards a Politics of Location (1984)." Blood, Bread and Poetry: Selected Prose, 1979-1985. New York: W.W. Norton and Company, 1986. 210-231.

Shands, Kerston W. Embracing Space: Spatial Metaphors in Feminist Discourse. London: Greenwood, 1999.

Séllei, Nóra. Miért félünk a farkastól? Feminista irodalomszemlélet itt és most. Debrecen: Kossuth Egyetemi Kiadó, 2007.

Szécsi, Noémi. Finnugor vámpír. Budapest: Kijárat Kiadó, 2002.

Szécsi, Noémi. The Finno-Ugrian Vampire. Trans. Peter Sherwood. London: Stork Press, 2012. 
Szilva, Eszter. “A Women's Turn in Literature? Women's Literature in Hungary in the Last Decade and its Connections to Feminist Politics." MA Thesis, Central European University, 2011.

Szolláth, Dávid. "Inventory of Magical Textual Constructions of the Unnatural in Hungarian Postmodern Fiction.” Neohelicon 45 (2018): 461-477.

Upstone, Sarah. “'Same Old, Same Old': Zadie Smith's White Teeth and Monica Ali’s Brick Lane." Journal of Postcolonial Writing 43.3 (2007): 336-349.

Várnagyi, Márta. “A női irodalom és a feminist irodalomkritika Magyarországon: Hangok és visszhangok." Társadalmi Nemek Tudománya Interdiszciplináris eFolyóirat 1.1 (2011): 23-35.

Vieten, Ulrike M. Gender and Cosmopolitanism in Europe: A Feminist Perspective. London: Routledge, 2012.

Wilson, Elizabeth. The Contradictions of Culture: Cities, Culture, Women. London: SAGE, 2001.

Wilson, Elizabeth. The Sphinx in the City: Urban Life, the Control of Disorder, and Women. Berkeley: University of California Press, 1992.

Woolf, Virginia. Three Guineas. London: Harvest, 1966.

\section{| Abstrakt}

\section{ÁGNES GYÖRKE}

Współczesne węgierskie pisarstwo kobiece i kosmopolityzm

Artykuł bada współczesne węgierskie pisarstwo kobiece w kontekście kosmopolitycznego feminizmu. Analizie poddano trzy utwory: Finnugor vampire Noémi Szécsi, Trans Noémi Kiss oraz Világító testek: 100 kis Budapest Erdős Virág. Utwory te czytam jako przykłady zaangażowania kosmopolitycznego feminizmu w przestrzeń miejską. W przeciwieństwie do kantowskiej koncepcji kosmopolityzmu, krytykowanej za nieuwzględnianie doświadczeń poszczególnych grup społecznych i regionów geograficznych, kosmopolityczny feminizm koncentruje się na tym, co lokalne i ucieleśnione. Omawiane dzieła dotyczą przekraczania granic pod względem zarówno formy, jak i treści, a jednocześnie angażują się w powszednie, afektywne aspekty codziennego życia w przestrzeni miejskiej. Ów kosmopolityczny feminizm kwestionuje zaściankowe, ciężkie, narodowe tradycje literackie i wskazuje na wyraźną linię estetyki feministycznej we współczesnej literaturze węgierskiej.

Słowa kluczowe: Węgry; literatura współczesna; pisarstwo kobiece; kosmopolityczny feminizm; przestrzeń miejska 


\section{| Abstract}

ÁGNes GYÖRKE

\section{Contemporary Hungarian Women's Writing and Cosmopolitanism}

This article investigates contemporary Hungarian women's writing in the context of cosmopolitan feminism. The literary works explored are Noémi Szécsi's The Finno-Ugrian Vampire, Noémi Kiss's Trans and Virág Erdős's Luminous Bodies: 100 Little Budapest, which I read as examples of a cosmopolitan feminist engagement with urban space. As opposed to the Kantian concept of cosmopolitanism, which has been critiqued for failing to take the experiences of particular social groups and geographical regions into account, cosmopolitan feminism focuses on the local and the embodied. The discussed texts thematise border crossing both on the level of form and content, while they engage with the mundane, affective aspects of everyday life in an emphatically urban setting. This cosmopolitan feminism challenges parochial, heavy, national literary traditions and points towards a distinct feminist aesthetics in contemporary Hungarian literature.

Keywords: Hungary; contemporary literature; women's writing; cosmopolitan feminism; urban space

\section{| About the Author}

Ágnes Györke is Associate Professor of English at Károli Gáspár University’s Institute of English Studies, Budapest, Hungary. She was a Visiting Scholar at Indiana University (2002-2003), the University of Bristol (January 2015), King's College London (June 2015), the University of Leeds (June-October 2016) and a Research Fellow at Central European University's Institute for Advanced Study (2012-2013). Her recent publications include "Doris Lessing's London Observed and the Limits of Empathy, Etudes Anglaises 70.1 (2017): 63-77 and "Stories from Elsewhere: The City as a Transnational Place in Doris Lessing's Fiction," From Transnational to Translational: Literature, Gender, Translation, ed. Sibelan Forrester, Jasmina Lukic and Borbála Faragó. Budapest: Central European University Press, 2019. Her edited volume entitled Geographies of Affect in Contemporary Literature and Visual Culture: Central Europe and the West is to be published by Brill in 2020 (co-editor: Imola Bülgözdi).

E-mail: gyorke.agnes@kre.hu 